\title{
Isolation and Molecular Characterization of $\beta$ - hemolytic Carnobacteriummaltaromaticum from Naturally Infected Longnose Parrot Fish (Hipposcarusharid) in Hurghada Red Sea, Egypt
}

\author{
Mahmoud Hashem Mohamed ${ }^{1}$, Islam Ibrahim Abogabal ${ }^{2}$ \& Einas H. El-Shatoury ${ }^{3}$ \\ ${ }^{1}$ Department of Fish Diseases and Management, Faculty of Veterinary Medicine, New Valley Branch, \\ Assuit University, El-Kharja, Egypt \\ ${ }^{2}$ Water quality management, Egyptian Environmental Affairs Agency (EEAA), Red Sea branch, \\ Hurghada, Egypt \\ ${ }^{3}$ Department of Microbiology, Faculty of Science, Ain Shams University, Cairo, Egypt
}

\begin{abstract}
This study focused on the isolation of bacteria causing hemorrhagic septicemia to longnose parrot fish in the Fishery Port at Hurghada Red Sea, Egypt. The examined fish showed hemorrhagic skin ulcers in the head, fins and body. Water sample was taken to determine the water physico-chemical properties and also to identic their relationship with the incidence of the bacterial hemorrhagic septicemia..Full bacteriological, biochemical, and molecular characterization of the isolated bacterium were done. The isolated bacterial isolate was identified as Carnobacteriummaltaromaticum. It is Gram positive, non-spore forming rods, salt requiring, chitinolytic, $\beta$-hemolytic bacteria. The antibiotic sensitivity test indicated that the isolate was sensitive to ofloxacin, gentamycin, ampicillin, streptomycin, erythromycin, nalidixicacid, amikacin, ciprofloxacin, colistin, chloramphinacol, neomycin, doxycycline, aminocidin, sulfisoxazole, penicillin $G$, bacitracin, and cefaclor. The incidence of infection with C.maltaromaticum among fish in the Fishery port was about 13\%. In this context, this is the first report of Carnobacteriummaltaromaticum from longnose parrot fish in warm water.
\end{abstract}

Keywords: Carnobacteriummaltaromaticum, longnose parrotfis, Red Sea.

\section{INTRODUCTION}

Fish resource sector with its natural fisheries and fish farming is seen as one of the vehicles for attaining food security and bridging the widening food gap, and is a major part of the Egyptian economy. It is one of the important traditional components of Egyptian citizen's meal, for its comparative cheap fresh protein (Mohamed et al., 2010). Fish are susceptible to a wide variety of bacterial pathogens. Many of these bacteria are capable of causing disease. These bacteria only become pathogenic when fishes are physiologically unbalanced, nutritionally deficient, or when exposed to other stressors, i.e., poor water quality, overstocking, which allow opportunistic bacterial infections to proceed. Most common pathogens of fish are Gram-negative rods such as, Aeromonas and Pseudomonas spp, which are more common in freshwater and Vibrio spp, more commonly isolated from marine environments (Petty and Floyd, 2015). On the other hand infections by Gram +v rods are caused by streptococcus Lactococcus, Enterococcus, Vagococcus. Carnobacteriumspp. appear to inhabit both the temperate and polar aquatic environments and was isolated from fish, marine sponges ( $\mathrm{Li}$ and Liu, 2006), Antarctic lakes (Franzmann et al., 1991;Bratina et al., 1998), Arctic and Antarctic sea water as well as the deep sea (Galkin et al., 1999; Groudieva et al., 2004; Newberry et al., 2004; Toffin et al., 2004; Lauro et al., 2007), and rivers in the northwest region of Spain (González et al., 1999). C. maltaromaticum was reported to be a fish pathogen "by" Cone, 1982; Hiu et al., 1984; Herman et al., 1985; Michel et al., 1986; Baya et al., 1991; Starliper et al., 1992; Toranzo et al., 1993;Leinseret al., 2007; Thomas et al. 2008; Thomas et al. 2011; Casaburiet al.2011; Schaffer et al. 2013.C.maltaromaticumdoesn't producecytochromeoxidase or catalase or $\mathrm{H}_{2} \mathrm{~S}$. The temperature and salinity tolerance ranges from10 to $37^{\circ} \mathrm{C}$ and 0 to $6 \% \mathrm{NaCl}$, respectively (Bayaet al., 1991). Other physical/ chemical parameters such as saltcontent, atmosphere and $\mathrm{pH}$ affect the survival and growth of these organisms in the natural 
environment. The presence of the $C$. maltaromaticum -like bacterium was associated with splenomegaly, renal and splenic congestion, and thickening of the swim bladder wall with accumulation of mucoid exudates (Thomas et al., 2008). External reddening and hemorrhage in the peritoneum, body wall, and viscera are symptoms characteristics to a disease known as hemorrhagic septicemia (Petty and Floyd, 2015; Moeller, R.B., 2016). The present study was conducted to identify the bacteria causing hemorrhage in long nose parrot fish in warm water, Hurghada, Red Sea and investigate the symptoms of infected fish.

\section{Materials ANd Methods}

Fish

Thirty (30) clinically diseased and moribund longnose parrot fish (Hipposcarusharid) were collected from Fishery port at Hurghada during summere 2014, they were subjected to clinical examination (Francis, 1999) and bacterial isolation.

\section{Water Samples}

Water samples were taken from the investigated Fishery port (control samples) in sterile bottles. Water temperature, $\mathrm{pH}$, salinity and dissolved oxygen were measured using a multi-probe sensor of Hydro lab Instrument "according to" Barreto et al., 2007. Biochemical oxygen demand (BOD) and chemical oxygen demand (COD) were determined by 5-Day BOD technique and open reflux method respectively, total ammonia was determined using Pye-Unicam Spectrophotometer (Model PU-8600).

\section{Bacterial Isolation}

Samples for bacterial isolation were taken from liver and spleen of moribund and clinically diseased longnose parrot fish(Hipposcarusharid) and cultured on plates of Tryptone Soya Agar (TSA) (Oxoid) supplemented with $2 \%$ (w/v) $\mathrm{NaCl}$. Plates were incubated at $30{ }^{\circ} \mathrm{C}$ for $2-5$ days (Farmer \&HickmanBrenner, 1992).

\section{Bacterial Characterization}

The distinct colonies were sub cultured on blood agar to select the hemolytic bacteria as described by Buxton (2013), colonies showing $\beta$ - hemolysis were characterized using the standard biochemical method as described by Alsina and Blanch (1994).Genomic DNA was extracted according to the manufacturer's instructions by boiling of 3 colonies in $100 \mu \mathrm{l}$ of highly purified water.

PCR amplification of partial 16S rRNA gene was performed using the primer pair PA (5'GAGTTTGATCCTGGCTCAG-3')and PH (5'-ACGGCTACCTTGTTACGACT-3').The PCR reaction mix was made up to $50 \mu \mathrm{l}$ with $100 \mathrm{ng}$ DNA, $30 \mathrm{nM}$ each primer and $25 \mu \mathrm{l}$ of Dream Taq master mix from Fermentas. The amplification was performed using Applied Bio system therclermocy. The protocol for PCR amplification was a 5 min denaturing step followed by 35 cycles of 1 min at $95^{\circ} \mathrm{C}$, $45 \mathrm{sec}$ at $60^{\circ} \mathrm{C}$ and $45 \mathrm{sec}$ at $72^{\circ} \mathrm{C}$ followed by a final extension step for $7 \mathrm{~min}$ at $72^{\circ} \mathrm{C}$. The amplified 16S rRNA gene was purified by Qiaquik gel extraction kit from (Qiagen). The product was sequenced using ABI 370x1 DNA sequencer using the forward primer. The nucleotide sequence was assembled in Bio Edit software (Hall, 1999). The nucleotide sequence was compared with similar sequences found in the NCBI database through BLAST program (www.ncbi.nlm.nih.gov/blast)). The nucleotide sequence was submitted to Gen Bank.

\section{Antibiotic Sensitivity Assay}

Sensitivity test was performed according to the manufacturer's instructions. TSA was supplemented with $2 \%(\mathrm{w} / \mathrm{v}) \mathrm{NaCl}$, plates were evenly inoculated with the colony under test. The following chemotherapeutic agents were employed: ofloxacin $5 \mu \mathrm{g}$, gentamycin10 $\mu \mathrm{g}$, ampicillin $10 \mu \mathrm{g}$,

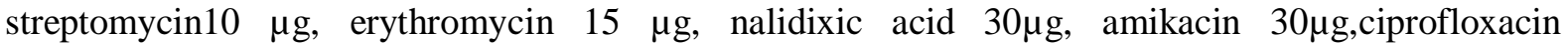
$5 \mu \mathrm{g}$,colistin $10 \mu \mathrm{g}$, chloramphinaco $130 \mu \mathrm{g}$, neomycin $30 \mu \mathrm{g}$, doxycycline $30 \mu \mathrm{g}$, aminocidin $60 \mu \mathrm{g}$, sulfisoxazole $300 \mu \mathrm{g}$, penicillin G10U, bacitracin10U, and cefaclor $30 \mu \mathrm{g}$. The susceptibility to antibiotics were determined according to the size of clear zones (Miranda and Zemelman, 2001).

\section{Results Clinical Signs}

The clinical signs of the diseased Hipposcarusharid fish were skin darkness, scales detachment, ulcers, small and large areas of hemorrhages distributed over many parts of the body, particularly at 
Isolation and Molecular Characterization of $\beta$ - Hemolytic Carnobacteriumm altaromaticum from naturally Infected Long Nose Parrot Fish (Hipposcarusharid) in Hurghada Red Sea, Egypt

fin bases, mouth region and abdomen area which varied in its severity from fish to another, representative sample is "shown in"Fig.1. The main post mortem lesions varied among fish samples; some fish showed varied degrees of congestion, enlargement of internal organs especially liver, spleen, kidney and distention of gall bladder. Additionally, congestion of intestines and accumulation of body fluids in the abdominal cavities are "shown in" Fig. 2.

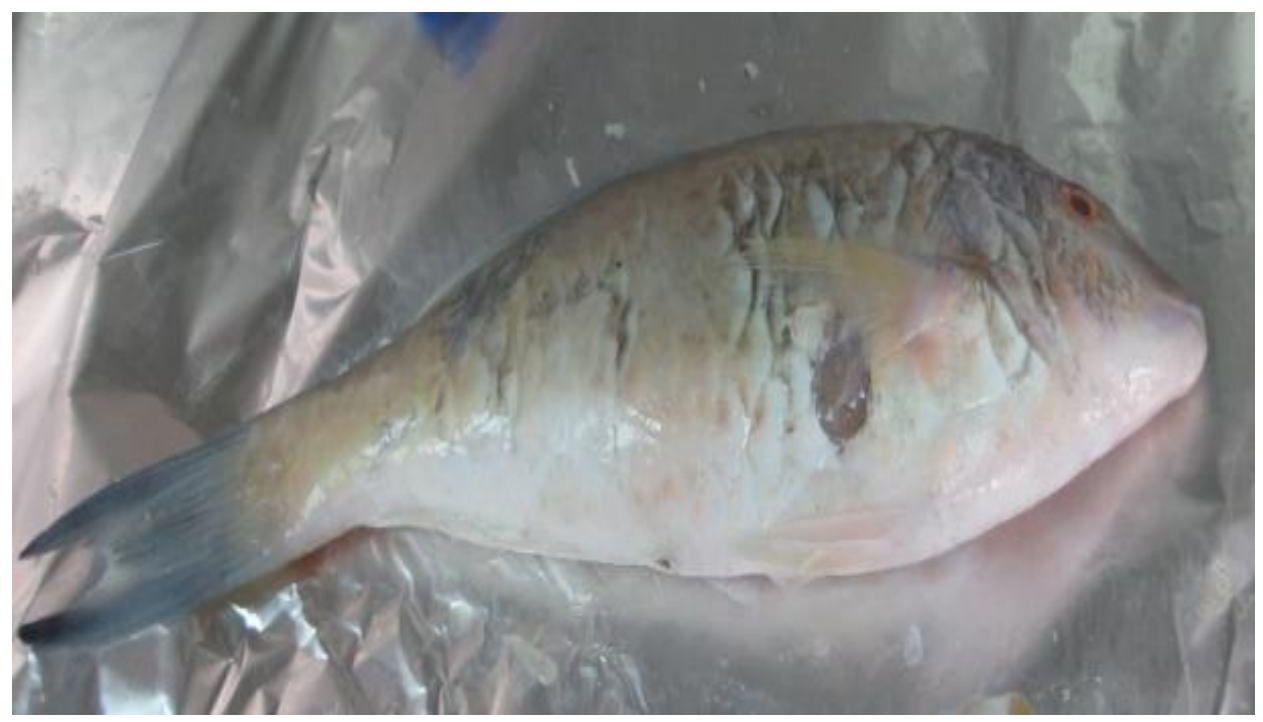

Fig 1. (Hipposcarusharid) with skin darkness and ulcers of varying sizes

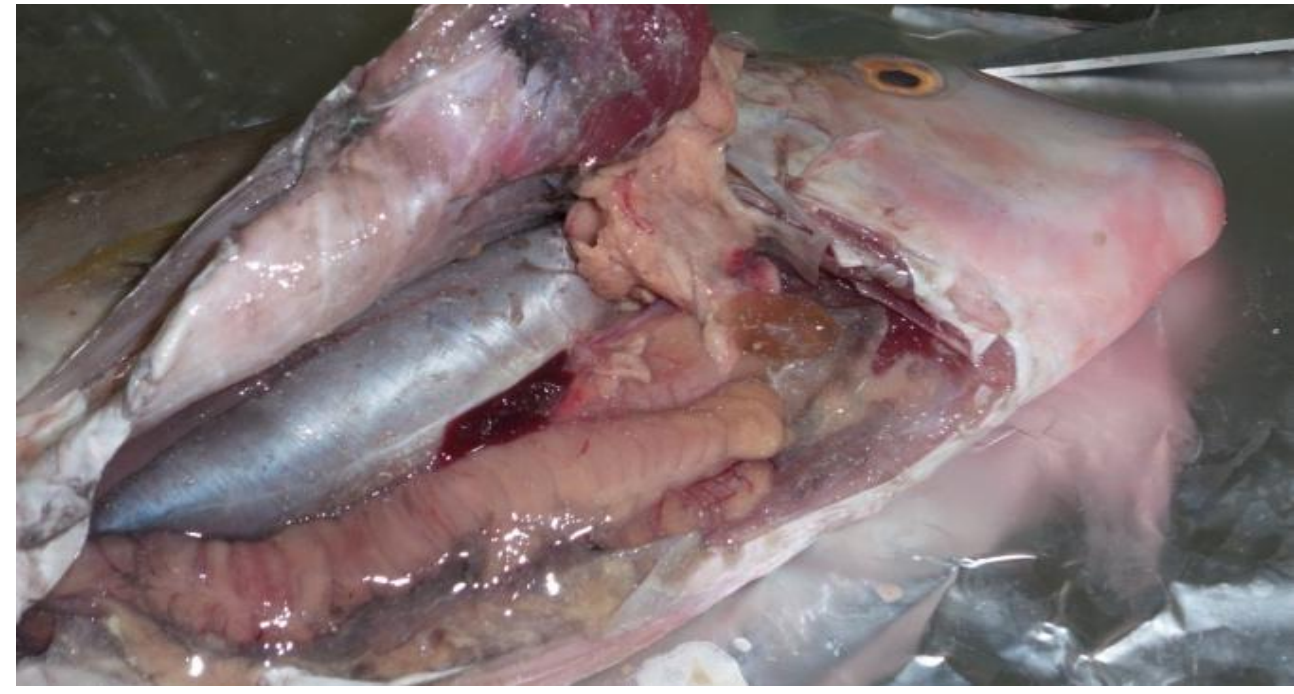

Fig 2. (Hipposcarusharid) with congested \& enlarged liver, spleen, kidney, and gall bladder distention

\section{Water Quality}

The results revealed that the average( taken from 5 readings)of water quality parameters during June 2014were as follow: dissolved oxygen (DO), surface water temperature, $\mathrm{pH}$, biological oxygen demand (BOD), chemical oxygen demand (COD) and ammonia recorded $3.49 \mathrm{mg} / \mathrm{l}, 31.66^{\circ} \mathrm{C}, 8.01$, $1.95 \mathrm{mg} / \mathrm{l}, 23.52 \mathrm{mg} / \mathrm{l}$ and $8.24 \mathrm{mg} / \mathrm{l}$ respectively.

\section{Bacterial Characterization}

The $\beta$ - hemolytic bacteria (Fig.3) were selected and subjected to biochemical and molecular characterization. Colonies produced on TSA were smooth, circular, buff-to-cream-colored and 10-15 $\mathrm{mm}$ in diameter with entire margins. The bacterial isolate was Gram positive rods, non motile, It didn't produce catalase, cytochrome oxidase or $\mathrm{H}_{2} \mathrm{~S}$; moreover, the isolate was negative in Citrate and indole production tests. They were positive to lysine decarboxylase, ornithine decarboxylase, arginine dehydrolase and $\beta$-galactosidase. The bacterial isolate produced acid from carbohydrates fermentation test (Glucose, Manitol, Arbinose). However, no acid was produced from other carbohydrates such as inositol, sorbitol, sucrose, melebiose, amygdalinose or rhaminose . 


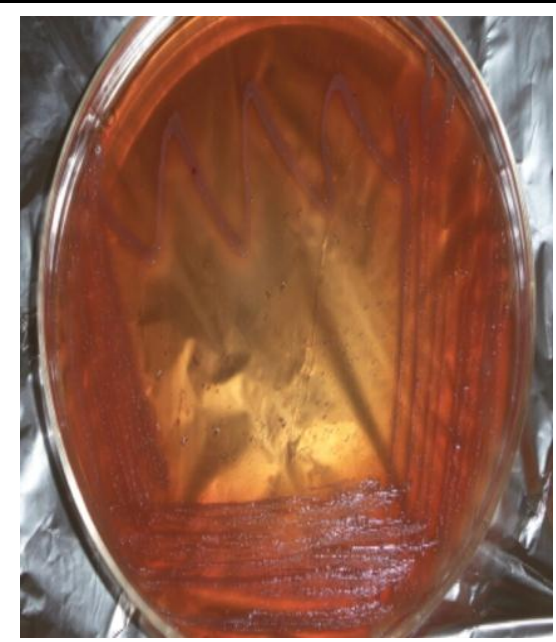

Fig 3. $\beta$ Hemolysis of $C$. maltaromaticum

\section{Molecular Characterization}

Sequencing of PCR product and comparison with NCBI data base resulted in the identification of bacterial isolate as C. maltaromaticum which was deposited in GenBank and "given the accession number of KY285267'(Fig.4).

$\mathbf{F}=$ Forward, $\mathbf{R}=$ Reverse

6F

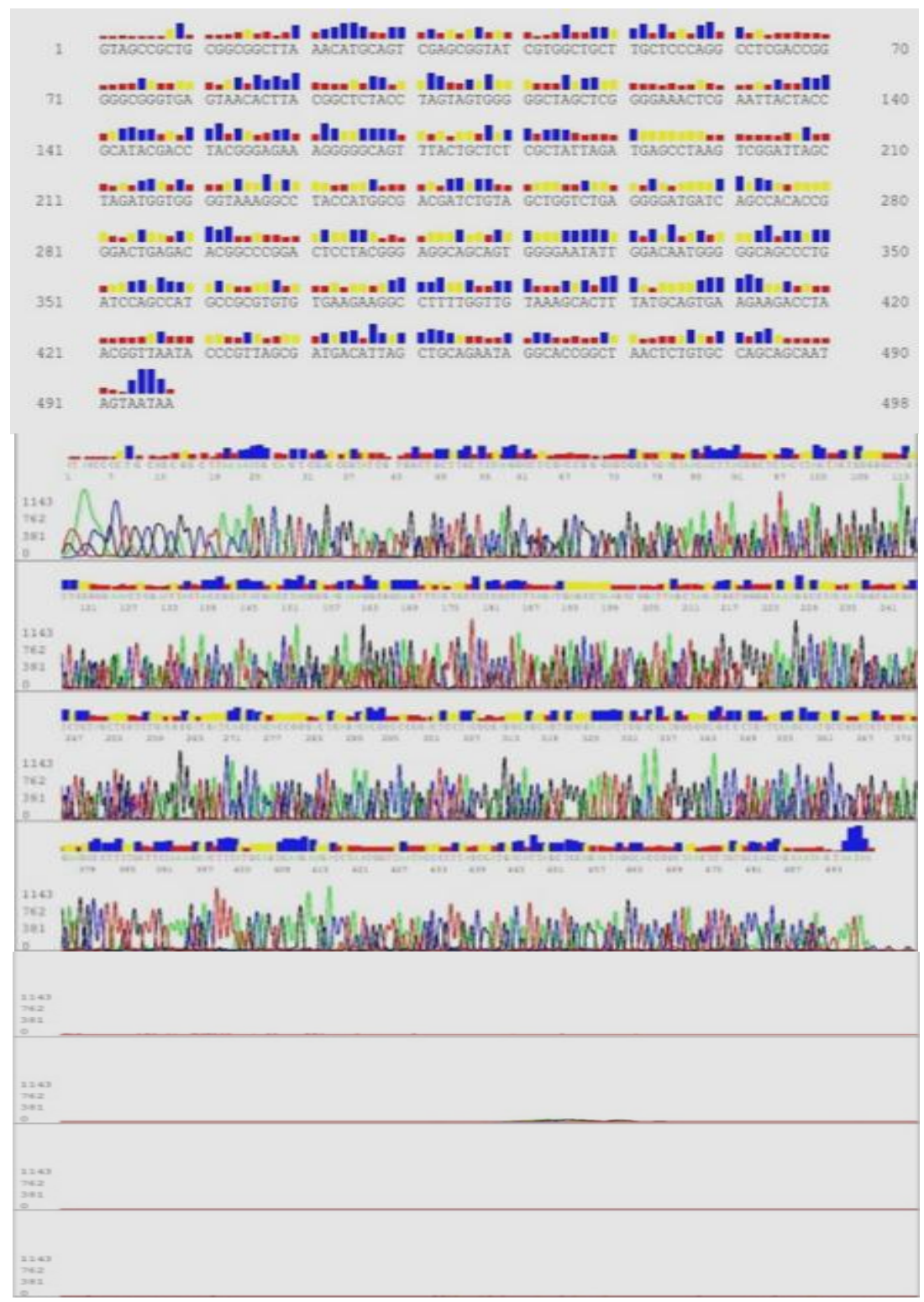


Isolation and Molecular Characterization of $\beta$ - Hemolytic Carnobacteriumm altaromaticum from naturally Infected Long Nose Parrot Fish (Hipposcarusharid) in Hurghada Red Sea, Egypt

6R

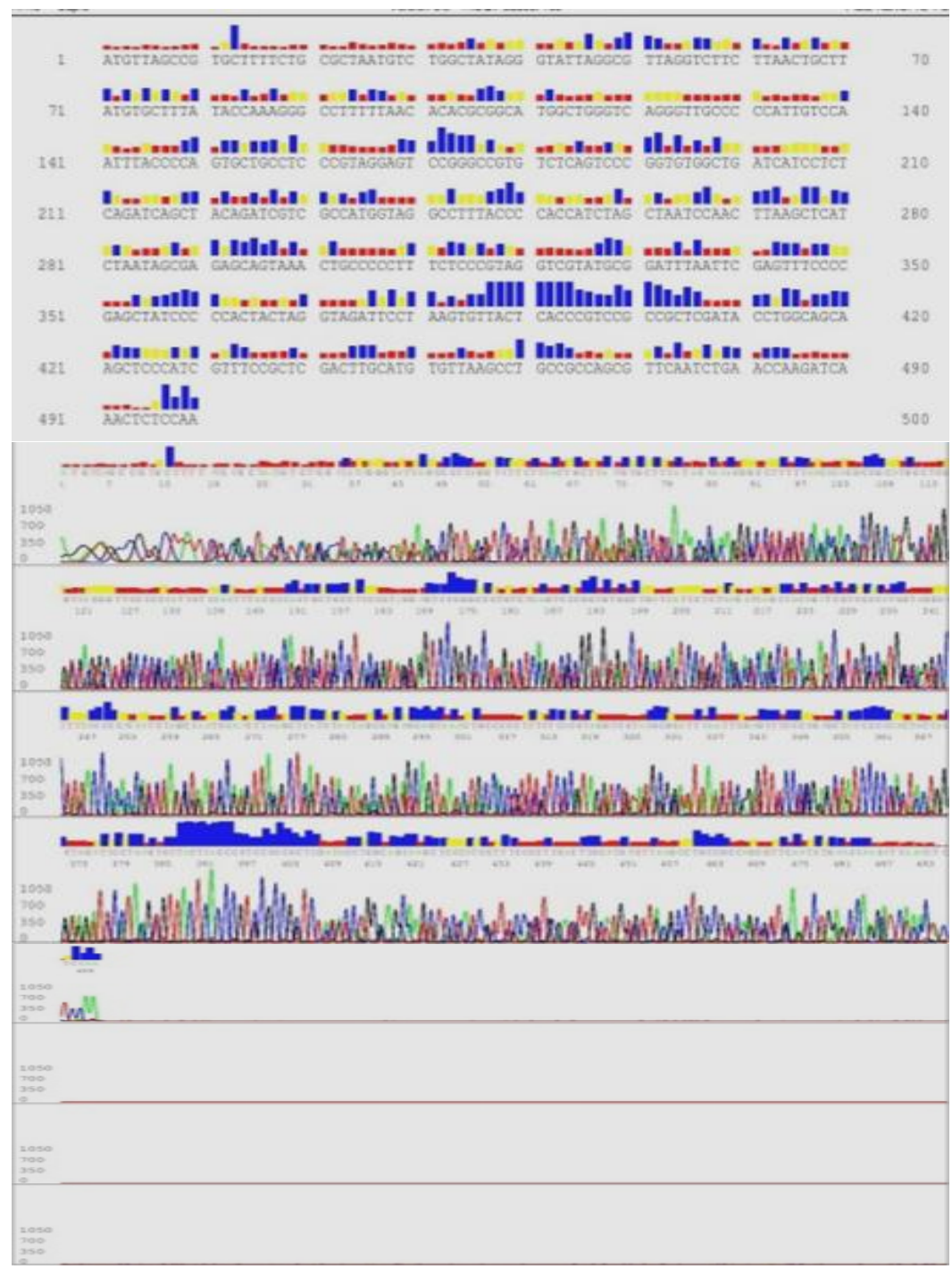

Fig 4. Nucleatide sequencing of C. maltaromaticum

\section{Antibiotic Sensitivity Assay}

The sensitivity test revealed that the isolated $C$. maltaromaticum was sensitive tostreptomycine, ofloxacin, ampicillin, nalidixic acid, amikacin erythromycin, chloramphinacol, neomycin, doxycycline, aminocidin, sulfisoxazole, ciprofloxacin, colistin, gentamycine, bacitracin, and cefaclor. as "shown in" Fig.5.

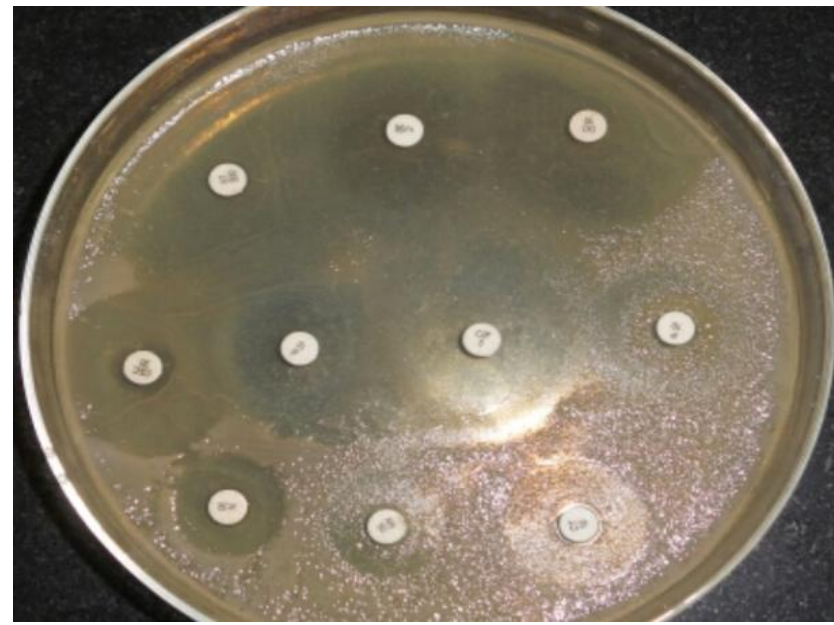

Fig 5. Antibiotic sensitivity test with disc diffusion of $C$. maltaromaticum 


\section{DISCUSSION}

Although Carnobacteriummaltaromaticum was reported to be a fish pathogen by many authors (Cone, 1982; Hiu et al., 1984; Herman et al., 1985; Michel et al., 1986;Baya et al., 1991; Starliper et al., 1992; Toranzo et al., 1993; Leinser et al., 2007; Thomas et al. 2008; Thomas et al. 2011; Casaburiet al.2011; Schaffer et al. 2013), this is the first report in Egypt for the infection of Longnose parrot fish by C.maltaromaticum. The clinical signs of $C$. maltaromaticum infection in longnose parrot (Hipposcarusharid) fish are similar to other bacterial infections such as vibriosis, that were skin darkness, scales detachment, ulcers, small and large areas of hemorrhages distributed over many parts of the body. The post mortem lesions revealed congestion in liver, spleen, intestine, stomach (gastro enteritis) and kidney and enlargement of gall bladder. Similar observations were found in red mouth disease in fish (Kumar et al., 2015), and lake white fish (Thomas et al., 2008). The onset of the disease may be attributed to the suppression of the fish immune system due to decreased dissolved oxygen and increased ammonia values due to the increase in numbers of tourists and/or visitors in the recreational areas, and thus increasing the microbial pollution. The recorded dissolved oxygen of the Fishery port was $3.49 \mathrm{mg} / \mathrm{l}$ which is relatively lower than the average DO of the specified criteria according to Egyptian Environmental Lawglnesuid (Not less than $4 \mathrm{mg} / \mathrm{l}$ ), BOD and recorded 1.95 $\mathrm{mg} / \mathrm{l}$ and $23.52 \mathrm{mg} / \mathrm{l}$ respectively that were lower than the criteria of Egyptian Environmental Law, on the other hand ammonia recorded $8.24 \mathrm{mg} / \mathrm{l}$ that was higher than the limits assigned by criteria of Egyptian Environmental law (3mg/l). Suomalainenet al. (2005) reported that the sharp increase in the ammonia level, water $\mathrm{pH}$, physical contact and the sharp decrease in the dissolved oxygen are the most possible triggering factors for the initiation, establishment and spread of infection because these factors might jeopardizing the fish immune system. The $\beta$ - hemolytic organism was suspected to be responsible for hemorrhagic symptoms; it was identified as $C$. maltaromaticum by the colony characters, cell morphology, Gram stain reaction, biochemical reactions and molecular identification using 16SrRNA. C. maltaromaticumwas differentiated from other species by hemolysis test. To the best of our knowledge this is the first record of $\beta$ - hemolytic activity in $C$. maltaromaticum, where previous reports (Baya et al., 1991; Leinser et al., 2007 Thomas et al., 2008;; Afzal et al., 2010 and Thomas et al., 2011) indicated $\alpha$ hemolytic activity of $C$. maltaromaticum. The antibiotic sensitivity test of $C$. maltaromaticumrevealed that the isolated strain was sensitive tostreptomycine, ofloxacin, ampicillin, nalidixicacid, amikacin erythromycin, chloramphinacol, neomycin, doxycycline, aminocidin, sulfisoxazole, ciprofloxacin, colistin, gentamycine, bacitracin, and cefaclor. It is to be noted that Leinser et al., 2007described the positive and negative effects using Carnobacteria as probiotis in the environment and in food. This study highlights the importance of taking precautions before applying bacteria on large scale because of possible negative impact on human health. The extensive use of antibiotics in aquaculture to prevent bacterial infection may result in the emerging of antibiotics resistant strains, therefore It is a matter of importance in the field of fish disease control to find out other means of controlling the infection in aquaculture rather than use of antibiotics.

In conclusion the morphological, biochemical, and molecular assays performed in this study confirm that bacteria isolated from longnose parrot fish was $C$. maltaromaticum, this is the first report for isolation of Carnobacteriummaltaromaticumfrom longnose parrot fish in warm water of Hurghada, Red sea, Egypt. This finding illustrates that Carnobacterium spp. can potentially infect large portions of resident longnose parrot fish populations if conditions favorable for an epizootic occur. The implications of these outbreaks of disease are currently unknown and warrant further investigation

\section{REFERENCES}

[1] Afzal, M. I., Jacquet, T., Delaunay, S. Borges, F., Millière, J.B., Junelles, A.M.R. and Grimal, C. C.2010.Carnobacteriummaltaromaticum: Identification, isolation tools, ecology and technological aspects in dairy products. Food microbiology, 27(5):573-579.

[2] Alsina, M. and Blanch, A.R.1994 .A set of keys for biochemical identification of environmental Vibrio species .Journal of Applied Bacteriology, pp. 79-85.

[3] Barreto, W. J., Scarminio, I., Solci, M.C., Ishikawa, D. N., Ogasawara, M. T., Nomi, S. N. and Barreto, S. R. G.2007. Analysis of Physical and Chemical Parameters for Discrimination of Water Origin in a Hydroelectric Reservoir. Clean, 35 (3): 239 - 245. 
Isolation and Molecular Characterization of $\beta$ - Hemolytic Carnobacteriumm altaromaticum from naturally Infected Long Nose Parrot Fish (Hipposcarusharid) in Hurghada Red Sea, Egypt

[4] Baya, A.M., Toranzo, A.E., Lupiani, B., Li, T., Roberson, B.S. and Hetrick,F.M. 1991. Biochemical and serological characterization Carnobacterium spp. isolated from farmed and natural populations of striped bass and catfish. Appl. Environ.Microbiol.57: 3114-3120.

[5] Bratina, B.J., Stevenson, B.S., Green, W.J. and Schemidt, T.M.1998. Manganese reduction by microbes from oxicregions of the Lake Vanda (Antarctica) water column. Appl. Environ.Microbiol.64:3791-3797.

[6] Buxton, R. 2013, Blood Agar Plates and Hemolysis Protocols. American society for microbiology.ML. Microbe Library.

[7] Casaburi, A., Nasi, A., Ferroncino, I., Monaco, R.D., Mauriello, G., Villani, F. and Ercolini, D.2011. Spoilage-Related Activity of Carnobacteriummaltaromaticum Strains in Air-Stored and Vacuum-Packed Meat. Appl. Environ. Microbiol. 77(20):7382-7393.

[8] Cone, D.K. 1982. A Lactobacillus sp. from diseased female rainbow trout, Salmogairdnerl Richardson, in Newfoundland, Canada. J FishDis., 5: 479-485.

[9] Farmer, J. J. and Hickman-Brenner, F. W.1992. The genera Vibrio and Photobacterium. In The Prokaryotes. A Handbook on the Biology of Bacteria: Ecophysiology, Isolation, Identification, Applications, $\left(2^{\text {nd }}\right)$ edn., pp. 2952-3011.

[10] Francis, F. R.1999. Clinical examination of fish in private collections. Vet Clin North Am ExotAnimPract., 2 (2):247-64.

[11] Franzmann, P.D.,Hopfl,P., Weiss,N. and Tindall,B.J. 1991.Psychrotrophic, lactic acid-producing bacteria from anoxic waters in Ace Lake, Antartica; Carnobacteriumfunditum sp. nov.and Carnobacteriumalterfunditum sp. nov. ArchivMicrobiol.156:255-262.

[12] Galkin, A., Kulakova, L., Ashida, H., Sawa, Y. and Esaki, N.1999.Cold-adapted alanine dehydrogenases from two Antarctic bacterial strains: gene cloning, protein characterization, and comparison with mesophilic and thermophilic counterparts. Appl Environ Microbiol., 65:40144020.

[13] González, C.J., López-Díaz, T.M., García-López, M.L., Prieto, M.and Otero, A.1999. Bacterial microflora of wild brown trout (Salmotrutta), wild pike (Esoxlucius), and aquacultured rainbow trout (Oncorhynchusmykiss) J Food Prot., 62:1270-1277.

[14] Groudieva, T. Kambourova, M., Yusef ,H., Royter, M., Grote, R., Trinks, H. and Antranikian, G..2004. Diversity and cold-active hydrolytic enzymes of culturable bacteria associated with Arctic sea ice, Spitzbergen. Extremophiles., 8:475-488.

[15] Hall, T.A.1999.BioEdit a user - friendly biological sequence alignment editor and analysis program for windows 95/98/NT. Nucleic acids symposium series, 41:95-98.

[16] Herman, R.L., McAllister, K., Bullock, G.L. and Shotts, E.B. 1985.Postspawning mortality of rainbow trout (Salmogairdneri) associated with Lactobacillus. J Wildl Dis, 21: 358-360.

[17] Hiu, S.F., Holt, R.A., Sriringanathan, N., Seidler, R.J. and Fryer, J.L. 1984. Latcobacilluspiscicola, a new species from salmonid fish. Int J SystBacteriol., 34: 393-400.

[18] Kumar,G., Ledouble, S.M., Saleh, M. and El-Matbouli, M. 2015.Yersinia ruckeri, the causative agent of enteric red mouth disease infish.PMC Vet. Res., 46(1):103.

[19] Lauro, F.M., Chastain, R. A., Blankenship, L.E., Yayanos, A. A. and BartlettD. H. 2007. The unique 16S rRNA genes of piezophiles reflect both phylogeny and adaptation. Appl. Environ. Microbiol., 73:838-845.

[20] Leisner, J.J., Laursen, B.G., Prévost, H., Drider, D. and Dalgaard, P. 2007."Carnobacterium: positive and negative effects in the environment and in foods. FEMS Microbiology Reviews, 31(5):59-613.

[21] Li, Z.Y. and Liu, Y.2006.Marine sponge Craniellaaustrialiensis-associated bacterial diversity revelation based on 16SrDNA library and biologically active Actinomycetes screening, phylogeneticanalysis. Lett. Appl. Microbiol., 43:410-416.

[22] Miranda, C.D. and Zemelman, R.2001.Antibiotic Resistant Bacteria in Fish from the Concepción Bay, Chile. Marin Pollution Bulletin, 42(11):1096-1102.

[23] Michel, C., Faivre, B. and Kerouault, B. 1986.Biochemical identification of Lactobacillus strains from France and Belgium. Dis. Aquat. Org., 2: 27-30. 
[24] Moeller, R.B.2016. Bacterial diseases of fish. Cichlid-forum.com.

[25] Mohamed, S.M., Ahmed, M.K. and Aly, K.I.A.2010.An analytical economic study of Egyptian fisheries. Journal of American Science, 6(9): 768-772, ISSN: 1545-1003.

[26] Newberry,C.J.,Webster,G., Cragg,B.A., Parkes,R.J.,Weightman,A.J. and Fry, J.C. 2004. Diversity of prokaryotes and methanogenesis in deep subsurface sediments from the Nankai Trough, Ocean Drilling Program Leg 190. Environ. Microbiol., 6:274-287.

[27] Petty, B.D. and Floyd, R.F., 2015.Bacterial Diseases of Fish. Merck veterinary manual.

[28] Schaffer, P.A., Lifland, B., Van Sommeran, S., Casper, D.R.and Davis, C.R. 2013. Meningoencephalitis associated with Carnobacteriummaltaromaticum-like bacteria in stranded juvenilesalmon sharks (Lamnaditropis). Vet Pathol. 50(3): 412-7

[29] Starliper, C.E., Shotts, E.B. and Brown, J. 1992. Isolation of Carnobacteriumpiscicola and an unidentified Gram positive bacillus from sexually mature and post-spawn in grain bow trout Oncorhynchusmykiss. Dis.Aquat. Org., 13:181-187.

[30] Suomalainen, L.R., Tiirola, M. andValtonen, E.T.2005. Influence rearing conditions on Flavobacteriumcolumnare infection of rainbow trout, Oncorhynchusmykiss (Walbaum). Journal of Fish Diseases, 28(5):271-277.

[31] Thomas, P. L., Wei, X., Scott, M. F. and Mohamed, F.2008. Isolation of a Carnobacteriummaltaromaticum like bacterium form systemically infected lake white fish (Coregonusclupeaformis). FEMS MicrobiolLett, 288: 76-84.

[32] Thomas, P.L., Rakesh,K., Wei, X. and Mohamed,F. 2011. Carnobacteriummaltaromaticum infections in feral Oncorhynchusspp. (family salmonidae) in Michigan. The Journal of Microbiology, 49 (5):703-713.

[33] Toffin L., Webster, G., Weightman, A.J., Fry, J.C., and Prieur, D. 2004. Molecular monitoring of culturable bacteria from deep-sea sediment of the Nankai Trough, Leg 190 Ocean Drilling Program. FEMS Microbiol. Ecol., 48:357-367.

[34] Toranzo, A.E., Romalde, J.L., Nunez, S., Figueras, A. and Barja, J.L. 1993.An epizootic in farmed, market-size rainbow trout in Spain caused by a strain of Carnobacteriumpiscicola of unusualvirulence. Dis. Aquat. Org., 17: 87-99. 